12 Diversities of international and transnational migration in and beyond Latin America

0000-0001-6528-599X

[ORCID 0000-0003-4674-7233] 
Running Head Right-hand: International and transnational migration Running Head Left-hand: Cathy Mcllwaine and Megan Ryburn

\title{
12
}

\section{Diversities of international and transnational migration in and beyond Latin America}

\author{
Cathy McIlwaine and Megan Ryburn
}

\section{Introduction}

Referred to by Durand and Massey (2010) as a series of 'new world orders,' the population flows into and out from Latin America since the 1500s have been characterized by huge diversity. Not only has the direction of flows changed over time, but migrants have moved to the continent, they have left, they have moved within and they have maintained complex transnational ties across borders. More than merely reflecting multiple patterns of mobilities, these movements have been the cornerstone of nation-building in Latin America, underpinned by expressions of intersectional power, exclusions, and inequalities (Wade, 2010). Furthermore, they act as important barometers of socio-economic, political, and cultural change in the continent and other parts of the world. This chapter traces these processes focusing on three sets of movements: first, early flows from Europe to Latin America; second, migration from Latin America to Europe and the United States (US); and third, movements within Latin America, before exploring the ways in which transnational ties link these together. The chapter also argues that these processes are often underpinned by inequalities of power manifested in multiple ways, and that the complexities, multidirectionality, and transnationality of migration within and beyond Latin America is often overlooked and simplified. 


\section{Multiple temporalities and spatialities of international migration flows: from Europe to Latin America}

While an excavation of the meanings of the 'Age of Discovery' and the nature of colonial endeavours and exploitation is beyond the scope here, it is important to note that the movement of Spanish and Portuguese to what was 'invented' as the 'New World' or Latin America (Mignolo, 2005), were in effect among the first migrants to the continent. Undergirding the colonization process was slavery, which although not migration per se, entailed the forced movement of more than 12 million people from the African continent to Latin America from 1500s until the 1800s (Durand and Massey, 2010: 22). At the same time, relatively small numbers of migrants from Europe and the Middle East began to settle in various countries across the region. This 'mixing' of peoples came to be referred to as 'miscegenation' or 'mestizaje/mestiçagem' which has been interpreted both positively in terms of a 'racial democracy' and negatively as rooted in racism (Wade, 2010, 2017).

Not until the second half of the 19th century did people move in large numbers to Latin America from Europe and various parts of Asia. Between this time and the 1950s, European migrants, mainly from Italy, Spain, and Portugal moved primarily to Argentina, Brazil, Cuba, Uruguay, and Chile (approximately 7.5 million people) (Durand and Massey, 2010: 22). Indeed, Italians, Spanish, and Portuguese constituted over two-thirds of migrants to Latin America between 1870 and 1930 (Goebel, 2016: 2). More specifically, Argentina has often been identified as the country with the largest numbers of European migrants settling; between 1820 and 1932, more than 6 million moved there (followed by more than 4 million to Brazil) (Padilla and Peixoto, 2007) (see below). The scale of these movements, especially between 1880 s and 1930 was 'quantitatively unprecedented' as a global mass movement of people (Goebel, 2016: 2) and arguably created one of the 'new global orders.' Although there were many more migrants moving from Europe to the US at this time rather 
than Latin America, in some specific countries such as Argentina and Uruguay, the ratio of arrivals to residents exceeded that of the US (ibid).

The reasons explaining international migration patterns are complex although one common factor lay in racial engineering. It is often argued that European migration was favoured by Latin American elites who sought to encourage it as a way of 'whitening' and thus, purportedly, 'improving' the population (Wade, 2017; see Bastia and Vom Hau, 2014). However, this has been challenged as too simplistic. For example, although Mexico and the Dominican Republic nurtured desires for racial 'whitening' with attempts to lure European settlers, this was never realized despite some migration of Chinese and Middle Eastern migrants to Mexico and the acceptance of 750 Jewish refugees from Nazi Germany to the Dominican Republic in 1937 (Goebel, 2016). In reality, the reasons for moving were multiple and depended on labour demand, access to land, and high salaries together with immigration policies in Latin America as well as poverty, hardship, and politics in Europe and beyond, not to mention improved transport and communication (Padilla and Peixoto, 2007).

The exact nature of these flows took different forms depending on the country and the time period. For instance, Chinese migration was concentrated in Peru where migrants moved to work on coastal plantations, as well as to the Panama Canal and sugar and banana plantations in Cuba, the Dominican Republic, and Costa Rica throughout the late 19th and early 20th centuries. The Japanese moved to Latin America after the slowdown of the main flows from Europe, moving primarily to Brazil (approximately 190,000) and Peru (approximately 20,000) (Durand and Massey, 2010: 22). This complexity was compounded first, by migrants moving within Latin America when they arrived (see below), and second, by mislabelling certain nationality groups. For instance, Germans who migrated to Argentina were really from the Lower Volga in Russia while 12,000 Irish who settled there in the 19th century were referred to as English (Goebel, 2016: 10). Furthermore, around half of all European migrants in the late 19th and early 20th centuries returned home (ibid.: 
6). This was especially common among Spanish and Portuguese who returned usually when they failed economically (Padilla and Peixoto, 2007).

Therefore, while this period of migration was critically important in nation-building in Latin America, the flows were much more multifaceted and dynamic than originally thought, especially in relation to intra-regional migration. Yet they also laid the foundations for subsequent transnational ties between Latin America and the rest of the world as the predominant flows broadly changed direction in the $1950 \mathrm{~s}$.

\section{Multiple temporalities and spatialities of international migration flows: from Latin America to Europe and beyond}

Variations in global economic and political development within and beyond Latin America continued to fuel international migration into and out from the region after the Second World War. However, this period marked a shift from migrants arriving in Latin America towards emigration elsewhere. Not only did post-war reconstruction and subsequent economic growth in Europe mean that people were less likely to want to migrate abroad, but population growth and Import Substitution Industrialization (ISI) in many Latin American countries brought economic improvements meaning that much migration was rural-urban and closely related with urbanization processes (Pellegrino, 2000) (see below). Yet, labour demand in the US in the 1940s and 1950s still meant that Puerto Rico and Mexico provided abundant supplies of low-wage migrant labour in agriculture and services. While as US citizens Puerto Ricans could move relatively easily, albeit on neo-colonial terms, Mexican migrants entered either as undocumented or through a range of guest worker programmes, including the Bracero Program in the 1940s (Calavita, 2010).

Cold War politics, US hegemony, and the rise of authoritarian regimes also played a

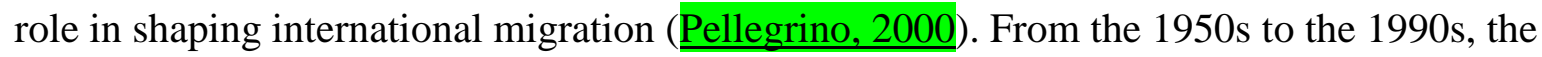


US was involved in direct interference or military interventions in many Latin American countries resulting in a range of different outcomes; in Cuba, following the 1959 Revolution, the US opened its doors to Cuban refugees, while the intervention in the Dominican Republic in 1965 led to out-migration of those on the Left to the US (Portes and

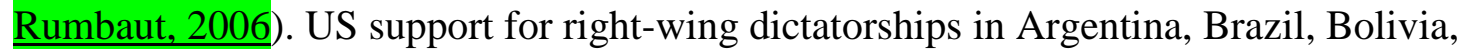
Guatemala, and Nicaragua also led to increased migration, much through exile, albeit varying according to country. For instance, while Nicaraguan refugees could secure permanent residence in the US, most Guatemalan and Salvadorans were only able to apply for temporary protected status (TPS) (Durand and Massey, 2010). The latter has since been rescinded in 2018 by the Trump administration for 200,000 Salvadorans residing in the US since 2001 following two earthquakes and joining withdrawals of TPS for 45,000 Haitians and Nicaraguans in 2017.

Although emigration grew significantly during this period, increasing from 1.6 million to 11 million in Latin America and the Caribbean between 1960 and 1990s (Pellegrino, 2000: 399), subsequent flows have been even higher. This was primarily linked with the imposition of neoliberal economic development models that supplanted ISI policies, and which led to widespread hardships throughout the continent as part of the 'Lost Decade.' In some cases, this led to a decline in skilled immigration, as in Venezuela where the oil industry had attracted many skilled workers from abroad (Durand and Massey, 2010), whereas in many others, people moved to escape poverty and improve their economic opportunities. Flows continued to increase to the US and other countries with significant ties to Latin America, such as Brazilians moving to Portugal and Japan (Pellegrino, 2000). This was facilitated in Japan by changes in the immigration system allowing descendants of Japanese to enter on favourable terms ( $\underline{\text { Tsuda, 1999). }}$

The turn of the millennium witnessed increased emigration, but also marked diversification. Between 2000 and 2010, 50\% of Latin Americans migrating (excluding Mexico) moved to the US, $24 \%$ to other Latin American countries, and $13 \%$ to Spain 
(OIM, 2015: 5). Although 9/11 led to some curtailment of flows into the US and contributed to diversification of European destinations (McIlwaine, 2011), movements into North America dominated; in 2015, 25 million migrants lived in the region representing an increase from 10 million in 1990. Around half of this comprised people born in Mexico (12.5 million), constituting the largest country-to-country migration corridor in the world (IOM, 2018: 75-76). There are important populations from Colombia, Peru, and Ecuador (more than 1.5 million), with recent growth from Paraguay, Venezuela, and Brazil linked with political and economic crises in these countries (IOM, 2017: 7).

Despite the dominance of Mexico-North American flows, 4.6 million Latin Americans resided in Europe, representing an increase from 1.1 million in 1990. While Spain was the primary destination with 1.8 million migrants, many also moved to Italy, Portugal, Sweden, the Netherlands, the UK, France, and Germany and were most likely to have moved from Colombia, Brazil, and Ecuador (IOM, 2018: 76). While early flows to Europe included Cubans for political reasons, as well as other exiles fleeing authoritarian regimes (such as Chileans moving to Sweden, Norway, and the UK), economic factors have dominated. These have included poverty, income inequality, and lack of opportunities in Latin America together with labour demand in the booming economies of southern Europe especially in care, cleaning, and construction sectors (prior to the crisis of 2008) (McIlwaine, 2011). These flows, which were largely feminized in nature, were further stimulated by socio-cultural similarities and existing family ties in Spain and Italy, together with favourable immigration legislation that encouraged migration through various bilateral regularization programmes (McIlwaine, 2012). Indeed, the gendered variations in migration patterns reflect both the gender ideologies in home countries as well as the nature of labour demand in destinations. Reflecting on migration to the US, Donato (2010) notes that feminized flows of Dominican migration compared to more masculinized flows from Mexico reflect flexible gender identities in the former and more 'traditional' ideologies in the latter. 
Although it is acknowledged that much contemporary movement beyond borders of Latin America revolves around economic exigencies, political circumstances have continued to play an important role. Just as Cold War geopolitics and authoritarian rule influenced migration in the second half of the 20th century, armed conflict and everyday violence in several countries precipitated contemporary movements. For example, the Colombian armed conflict has created the world's largest population of internally displaced peoples (7.2 million as of 2016) and extensive cross-border movements to Venezuela and Ecuador (IOM, 2018: 78). It has also led to international migration, or what has been termed 'transnational displacement' underpinned by threats to personal security and fear linked to everyday as well as political and gender-based violence and erosion of economic livelihoods (McIlwaine, 2014 on Colombians in London). In addition, everyday urban violence in many Central American countries and Mexico, often linked with gang and drug violence, has led to migration and burgeoning asylum claims. In 2015, there were $250 \%$ more asylum claims in the US from El Salvador, Honduras, and Guatemala between 2013 and 2015, and an increase of 155\% of claims from Mexicans in the US (IOM, 2018: 79). These contemporary processes are dynamic and in constant flux. South America has over 10 million emigrants with a regional average of $5.4 \%$ of the total population moving. However, while absolute numbers of emigrants are growing, there has been a slowdown between 2010 and 2015 (IOM, 2017). While this is partly linked with people being less likely to move, it also relates to the return of those born or naturalized abroad. For example, in 2015, 118,598 people from the US lived in South America, especially in Brazil and Ecuador. Similarly, following the 2008 recession, many Latin Americans with Spanish nationality returned home; in Ecuador, the stock of Spanish migrants increased between 2005 and 2015 from 3,658 to 7,473 (IOM, 2017: 5). There has also been an increase in migration from Africa and Asia as Europe and North America have become increasingly difficult to access. While the numbers from African countries are small, between 2004 and 2014, Argentina, Brazil, and Chile granted almost 50,000 permanent residency permits to 
Chinese citizens (of whom 58\% were male) (IOM, 2017: 5). Yet, for the region as a whole probably the most significant international migration dynamics relate to intra-regional flows.

\section{Multiple temporalities and spatialities of international migration flows: within Latin America}

Although intra-regional migration in Latin America has always been important, it has increased significantly recently. In South America, $70 \%$ of all migrations are within the region, now outnumbering extra-regional movements (IOM, 2017). Internal migration has also been integral to the creation of Latin American countries even if it has been overlooked (Rodríguez and Busso, 2009). Partly interrelated with internal migration across proximate borders has been rural-urban movements with the latter being rapid and contributing to the urbanization of the continent as a whole. While $41 \%$ of the region lived in urban areas in 1950s, this stood at $80 \%$ in 2014 - significantly higher than other regions (UN DESA, 2014). Factors motivating these processes include the dominance of ISI as an economic strategy, combined with changes in agricultural production, which also contributed to emigration (Cerutti and Bertoncello, 2003; see above). Today, internal migration is primarily urban-urban, which again feeds into international processes as most migrants moving abroad originate from cities (Mcllwaine and Bunge, 2016).

This has been accompanied by shifting and diversifying intra-regional migration which has tended to be strongly feminized (Martínez Pizarro and Orrego Rivera, 2016). Although extra-continental migration was the predominant form to Latin America from the colonial period into the early 20th century, from the 1920s, intra-regional flows - especially between neighbouring countries - began to gradually increase as migration from Europe declined. Argentina has historically been one of the main receptor countries and is 
emblematic of these patterns (see above). In 1914, migrants from outside Latin America comprised $27 \%$ of Argentina's total population, and migrants from neighbouring countries only $2.6 \%$ (Martínez Pizarro, 2011: 101). By 2000, migrants comprised $4.2 \%$ of the total, of which $60 \%$ were from neighbouring countries, principally Paraguay, Bolivia, Chile, and Uruguay (Martínez Pizarro, 2011: 101). By 2015, this had risen to 5\% (South America's highest average) (IOM, 2017: 2).

Argentina is joined by Costa Rica and Venezuela as countries that have traditionally had significant intra-regional migrant populations. In Costa Rica, migrants constituted 7.5\% of the total population in 2000 (CEPAL, 2006), rising to 9\% in 2015 (IOM, 2018: 76), mainly Nicaraguans. This represents the continuation of a trend that commenced in the late 19th century when the expansion of the banana plantations attracted Nicaraguan workers to Costa Rica (Fouratt and Voorend, 2017). Subsequently, Nicaraguans have gradually moved from agricultural to more urban-based employment (EPAL, 2006). This mirrors tendencies in Argentina, where intra-regional migrants were initially involved in the agricultural sector, but have progressively moved to the cities (Bastia, 2007).

As with all types of migration across borders noted above, intra-regional migration was spurred by both economic and political factors. In the case of Nicaraguan migration to Costa Rica, for example, in addition to economic instability, the armed conflict from 1978 to 1990 also compelled people to leave. Similarly, repression and human rights abuses in the Southern Cone dictatorships of the 1960s to the 1980s led to the exile of hundreds of thousands. Whilst people fled to all continents except Antarctica (see above), certain countries within Latin America, most notably Venezuela, were important hubs for refugees from the region. For example, Chilean exiles, comprising around 200,000 , or $2 \%$ of the country's 1973 population, settled in over 140 countries, but it is estimated that over $40 \%$ of them settled in Venezuela (Sznajder and Roniger, 2007).

Venezuela has also been a key destination for refugees and migrants from neighbouring Colombia seeking to escape armed conflict and everyday urban violence 
(McIlwaine, 2014; see above). For several decades, Colombians have constituted the largest intra-regional migrant population in Latin America. In 1990, there were approximately 600,000 intra-regional Colombian migrants, reaching 700,000 in 2000 with around 90\% moving to Venezuela (CEPAL, 2006: 23). In turn, Haiti currently sends the second largest number of refugees abroad linked with disasters (IOM, 2018: 78) while Central American migration directly to Mexico and transit migration through Mexico to the US has also been very significant (ibid.).

Much transit migration has been irregular, with apprehensions moving southwards. Indeed, in 2014 and 2016, arrests of Central Americans exceeded those of Mexicans trying to cross the Mexican-US border. These have also diversified to include Haitians as well as migrants of African and Asian origins trying to cross into the US via Mexico (IOM, 2018: 79). This burgeoning transit migration has entailed high levels of exploitation as well as structural and everyday violence and death among migrants as they negotiate their way towards their dream in the US, often via smuggling routes (Vogt, 2013). The response to transit and other intra-regional movements has been increased border enforcement, focusing especially on combatting smuggling and the associated industry. For example, Costa Rica closed its borders to Cubans in 2015 and to all irregular migrants in 2016, while Mexico implemented its Southern Border Plan in 2014 to reduce irregular migrant flows from Central America (IOM, 2018).

In the southern cone, Chile has also experienced recent increases in intra-regional migration. While in 1992 , there were an estimated 114,597 foreigners living there $(0.9 \%$ of the total population), this more than quadrupled to 465,319 migrants (or around $2.7 \%$ of the

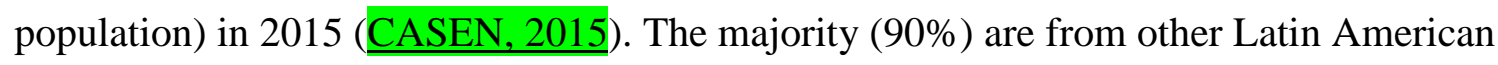
countries, but with an increasing diversity in countries of origin; previously most migrants were from Argentina and Peru, yet there are now growing numbers from Bolivia, Colombia, Venezuela, Dominican Republic, and Haiti. For example, the Colombian population in Chile has increased by $345 \%$ in the past decade (Rojas Pedemonte and Silva 
Dittborn, 2016) while the Bolivian population has increased markedly and concentrated in precarious employment in labour niches such as agriculture, domestic work, and wholesale garment retail (yurn, 2016). Other countries in the Southern Cone such as Brazil are also receiving increasing and diversified migration such as increasing Haitian migration ( $\underline{\underline{I O M}}$, 2017; OIM/IPPDH, 2017).

Another important economic factor affecting intra-regional migration has been the 2008 global economic crisis (see above). Whilst impacts have been felt throughout Latin America, they have been less severe than in the US or Europe. Indeed, some migrants to the US and Spain returned briefly to their countries of origin following the fall-out from the economic crisis, only to move onwards again to an intra-regional destination. Additionally, those who previously would have considered extra-continental migration became less inclined given the crisis and the relatively stable economies of certain countries such as Chile, which has been part of the OECD since 2013 (IOM, 2017). Furthermore, restrictive immigration regimes in the US and Europe also act as a deterrent to extra-continental migration (McIlwaine, 2015a). Migration regimes in Latin America are comparatively relaxed, although certainly not entirely unrestrictive; indeed, groups of certain nationalities and/or ethnicities and socio-economic backgrounds may face particular discrimination (Ryburn, 2018 on Chile).

Since 2010, Haiti and Venezuela have also seen a sharp spike in emigration prompted by a combination of factors. In Haiti, many people left in the aftermath of the disasters - from the year 2000 to 2010, just after the earthquake, Haitian migration rose by 392\%, from 64,360 to 317,054 (Martínez Pizarro and Orrego Rivera, 2016). The Dominican Republic received the vast majority of Haitians, but as indicated above, Brazil and Chile have also become important receiving countries (OIM/IPPDH, 2017). In Venezuela, intense political instability since the latter years of Hugo Chávez's presidency and following his death has prompted many to leave; an estimated 606,281 Venezuelans

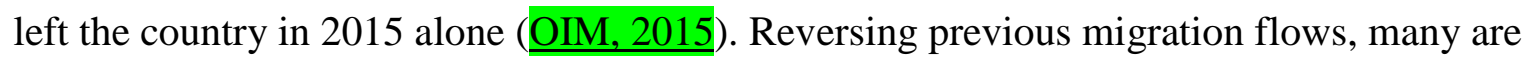


going to neighbouring Colombia, as well as to Argentina and Chile (IOM, 2017; $\underline{\text { Martínez }}$ Pizarro and Orrego Rivera, 2016).

The contemporary flows are indicative of the growing diversity of intra-regional migration in Latin America. Whilst this represents a new phase in Latin American migration, it is also consistent with what has been a very dynamic migration context over several centuries. The multiplicity of flows, motivations for migration, and transnational connections over time are therefore more complex than is often recognized.

\section{Transnationality in Latin America and beyond}

While the discussion above has delineated the main patterns and processes of migration into and out from Latin America, it is also important to identify the broader significance of these movements. While it is not the intention to rehearse the range of theoretical approaches that have been developed to understand international migration flows, it is important to show how some of the main conceptual framings play out in the Latin American context and how this context has shaped the theorizing in the first place. Whether this is related to maximizing earning power as in neo-classical theories, risk-sharing from a New Economics of Labour Migration (NELM) viewpoint, or household networks and strategies identified through structuration perspectives, various forms of inequalities

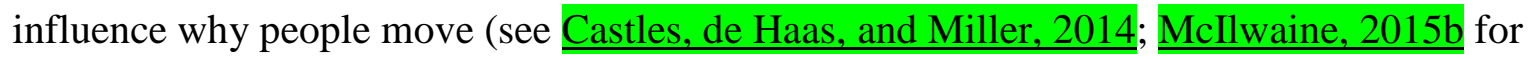
discussions). Yet these inequalities span source and destination countries and as a result, a relational approach is needed to understand international migration as part of a transnational system of ties, circuits, and spaces that link migrants and their lives together over space. While not exclusively, much research on transnationalism has drawn on Latin American and Caribbean examples (Basch, Glick Schiller, and Szanton, 1994).

Latin American transnationality has taken multiple forms. Analyses of political transnationality, for instance, tend to revolve around how Latino migrants have engaged in 
electoral and civic politics in the US, especially in terms of the mutually reinforcing nature of transnational political engagement and wider integration processes (Portes, Escobar, and Arana, 2008). However, this geographical focus has recently broadened to include the experiences of Latin Americans in European contexts. Research with Colombians in the United Kingdom (UK) and Spain has highlighted the gendered nature of political participation where working- rather than middle-class women are more active (McIlwaine and Bermudez, 2011), and the ambivalent forms of citizenship exercised in relation to external voting (McIlwaine and Bermudez, 2015). Not only does this demonstrate the gendered importance of politics in integration processes in destinations, but also the potential power of migrants in influencing politics back home, not least through remittance income.

Economic transnationalism is another core dimension of Latin American transnationality through remittance sending and their role in addressing development problems as part of the wider migration-development nexus. While sending money back home can be viewed as a key driver in reducing poverty (Acosta et al., 2008), international migrants make considerable sacrifices in order to send money home. Remittance receipts can also create social problems back home not least because of their dubious sustainability (Wills et al., 2010). Yet, remittances sent to Latin America continue to grow apace; in 2016, they grew nearly $8 \%$ compared to 2015, amounting to US\$70 billion (Orozco, 2017: 3). Despite their contradictory role, they are likely to remain a key economic driver and safety net in Latin America into the future. Furthermore, while much research on remittances has been on extra-continental flows, they are also extremely important across more proximate borders (Melde et al., 2014).

Social transnationality, maintained through 'social remittances' denoting “ideas, behaviours, identities and social capital that flow from receiving- to sending-country communities" and back again (Levitt, 1998: 926), are also increasingly recognized as important and indeed, provide the mechanisms through which to tie political, economic, 
and cultural links together. Referring to the Dominican Republic and the US, Levitt and Lamba-Nieves (2011) show how social remittances operate individually across borders between friends and families and collectively through civil society organizations as well as through the ideas and values that migrants take with them when they move). Religious remittances are part of wider forms of social remittances and can refer to the transfer of faith as people move, institutional links between churches across borders as well as virtual linkages through, for example, transmitting church services over the internet between countries ( $\underline{\text { Sheringham, 2013)}}$.

Another important dimension of this relates to gender and specifically how gendered power relations transform as women and men move (Donato, 2010; $\underline{\text { Mahler and }}$ Pessar, 2001). It is generally accepted that such transformations are contradictory, entailing some improvements in women's lives in relation to improved access to the labour market and the independence concomitant with having access to an income (Boehm, 2008). On the other hand, gender inequalities can be intensified, especially if women are undocumented or experience gender-based violence (McIlwaine, 2010). Furthermore, it is more difficult to change gender ideologies compared with gender practices, the latter being more malleable, and the outcomes for women vary in intersectional ways (ibid). Gender transformations must also be viewed within wider processes of inequality through the extension of transnational chains of emotional labour or 'global care chains' and "the international division of reproductive labour" (McIlwaine and Ryburn, 2018 for discussion). While much of this work refers to Latin Americans moving to the US and Europe in terms of women from poorer countries moving to carry out reproductive labour hitherto conducted by wealthier women who have entered the paid workforce (Hondagneu-Sotelo, 2001),

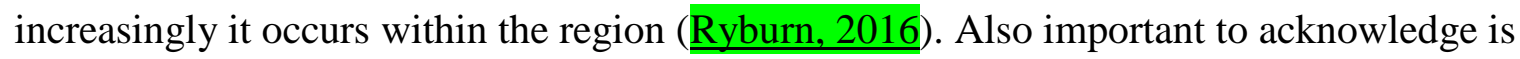
that women not only migrate, often becoming transnational mothers in the process, but they are also left behind in Latin America, especially as grandmothers, elder sisters, and other female relatives with caring responsibilities for children of migrants (ㅂerrera, 2013). 
Many aspects of these transnational ties can be combined into analyses of transnational social spaces. Although it is often assumed that transnational linkages are binational, Latin American migration has become more complicated often linking multiple countries and peoples together. From the perspective of Latin Americans in London, in 2010, 36.5\% had migrated via another country, with 38\% moving from Spain (Mcllwaine, 2012). Subsequently, research showed that $80 \%$ of Latin Americans who had migrated from Europe came from Spain through onward migration (McIlwaine and Bunge, 2016; also Mas Giralt, 2017). These mobility processes feed into the construction of multifaceted transnational spaces comprising families living across borders, remittances flowing not only back home to Latin America, but also to intermediate destinations, as well as a host of other ties through negotiations over immigration status, political engagements, and civil society organizations (McIlwaine, 2012, 2015a).

It is therefore important to acknowledge that Latin American international migration has created a diverse system of transnational spaces and multiple linkages both within the continent and beyond, often buttressed by inequalities of power. Although many wealthy professional and highly skilled Latin Americans move around the world with ease, and it is rarely the very poorest in society who move, most who move do so to enhance their social, economic, and/or political livelihoods. However, the reality of the outcomes of migrating, at least in initial stages can be extremely harsh. Again using the London example, half of Latin Americans recently arrived from Spain (who had EU citizenship) worked in low-paid, precarious cleaning jobs as their only option (usually because of English language difficulties). Their lives beyond the labour market were equally precarious with many sharing poor-quality, overcrowded accommodation with other families or individuals (McIlwaine and Bunge, 2016). These forms of precarity also prevailed (and are arguably worse) in intra-regional movements in terms of labour exploitation (McIlwaine and Ryburn, 2018), poor health provision (Gideon, 2014), and housing provision (Rojas Pedemonte and Silva Dittborn, 2016) especially when compared with than their native-born counterparts. 
Relatedly, across the world, Latin American migrants face frequent discrimination and racism in their everyday lives (Tijoux, 2016), and even physical violence, as among Central American migrants who transit through Mexico (Vogt, 2013). These hardships are likely to increase into the future as the Trump administration in the US implements ever more draconian measures to prevent migration and to deport those already settled there, many who originate in Latin America and especially Mexico where Trump's rhetoric has been especially insidious (see above). Such hostile migration regimes have been replicated in other parts of the world, especially in European countries, and are likely to contribute to increased intra-regional migrations within the continent.

\section{Conclusion}

This chapter has examined the nature of international and transnational migration within and beyond Latin America. Through tracing a range of temporal and spatial framings around flows into, out from, and within the continent, it has also assessed some of the core socio-economic and political reasons underlying these movements at different scales. As well as arguing that international migration has been integral in nation-making processes, it also suggests that a range of different forms of transnationality have tied people and countries together in multiple ways across borders. Overall, the chapter has argued for enhanced recognition of the complex diversities of international migration within and beyond Latin America; not only have these been more diverse than first thought in looking back historically, but are also likely to diversify further into the future, especially within the region. 


\section{References}

Acosta, P., Calderón, C., Fajnzylber, P. and Lopez, H. (2008) What is the impact of international remittances on poverty and inequality in Latin America? World Development 36: 89-114.

Basch, L., Glick Schiller, N. and Szanton Blanc, C. (1994) Nations Unbound. Amsterdam: Gordon and Breach.

Bastia, T. (2007) From mining to garment workshops: Bolivian migrants in Buenos Aires. Journal of Ethnic and Migration Studies 33(4): 655-669.

Bastia, T. and vom Hau, M. (2014) Migration, race and nationhood in Argentina. Journal of Ethnic and Migration Studies 40(3): 475-492.

Boehm, D. A. (2008) 'Now I am a man and a woman!' Gendered moves and migrations in a transnational Mexican community. Latin American Perspectives 35(1): 16-30.

Calavita, K. (2010) Inside the State: The Bracero Program, Immigration, and the I. N. S. New Orleans: Quid Pro Quo Books.

CASEN. (2015) Inmigrantes: principales resultados (versión extendida). Santiago, Chile: Observatorio del Ministerio de Desarrollo Social.

Castles, S., de Haas, H. and Miller, M. (2014) The Age of Migration. 5th Ed. Basingstoke: Palgrave Macmillan.

CEPAL. (2006) Migración Internacional. Santiago, Chile: América Latina y el Caribe Observatorio Demográfico.

Cerutti, M. and Bertoncello, R. (2003) Urbanisation and Internal Migration Pattern in Latin America. Buenos Aires: Centro de Estudios de Población Argentina.

Donato, K. M. (2010) US migration from Latin America: Gendered patterns and shifts. Annals of the American Academy of Political and Social Science 630(1): 78-92. 
Durand, J. and Massey, D. S. (2010) New world orders: Continuities and changes in Latin American migration. Annals of the American Academy of Political and Social Science 630(1): 20-52.

Fouratt, C. and Voorend, K. (2017) Sidestepping the state: Practice of social service commodification among Nicaraguans in Costa Rica and Nicaragua. Journal of Latin American Studies 'First view' October 16. https://doi.org/10.1017/S0022216X17001195 (Accessed 7 December 2017).

Gideon, J. (2014) Gender, Globalization, and Health in a Latin American Context. London: Palgrave Macmillan.

Goebel, M. (2016) Immigration and national identity in Latin America, 1870-1930. Oxford Research Encyclopedia of Latin American History. http://latinamericanhistory.oxfordre.com/view/10.1093/acrefore/9780199366439.00 1.0001/acrefore-9780199366439-e-288?print=pdf (Accessed 1 December 2017).

Herrera, G. (2013) Gender and international migration. Annual Review of Sociology 39(1): 471-489.

Hondagneu-Sotelo, P. (2001) Doméstica: Immigrant Workers Cleaning and Caring in the Shadow of Affluence. Berkeley, CA: University of California Press.

International Organization for Migration (IOM). (2017) South American Migration Report No. 1. Migration Trends in South America. Buenos Aires: IOM. https://robuenosaires.iom.int/sites/default/files/Documentos\%20PDFs/Report_Migr ation_Trends_South_America_N1_EN.pdf (Accessed 7 December 2017).

—. (2018) World Migration Report 2018. Geneva: OIM.

Levitt, P. (1998) Social remittances: Migration driven local-level forms of cultural diffusion. The International Migration Review 32(4): 926-948. and Lamba-Nieves, D. (2011) Social remittances revisited. Journal of Ethnic and Migration Studies 37(1): 1-22. 
Mahler, S. J. and Pessar, P. R. (2001) Gendered geographies of power: Analyzing gender across transnational spaces. Identities 7(4): 441-459.

Martínez Pizarro, J. (2011) Migración internacional en América Latina y el Caribe: Nuevas tendencias y nuevos enfoques. Santiago, Chile: CEPAL. and Orrego Rivera, C. (2016) Nuevas tendencias y dinámicas migratoria en América Latina y el Caribe. Santiago, Chile: United Nations/OIM/CEPAL.

Mas Giralt, R. (2017) Onward migration as a coping strategy? Latin Americans moving from Spain to the UK post-2008. Population, Space and Place 23(3): 1-12.

McIlwaine, C. (2010) Migrant machismos: Exploring gender ideologies and practices among Latin American migrants in London from a multi-scalar perspective. Gender, Place and Culture 17(3): 281-300.

. (2011) Introduction: Theoretical and empirical perspectives on Latin American migration across borders. In C. McIlwaine (ed) Cross-Border Migration Among Latin Americans: European Perspectives and Beyond. New York: Palgrave Macmillan, pp. 1-17.

. (2012) Constructing transnational social spaces among Latin American migrants in Europe: Perspectives from the UK. Cambridge Journal of Regions, Economy and Society 5(2): 271-288.

_. (2014) Everyday urban violence and transnational displacement of Colombian urban migrants to London, UK. Environment and Urbanization 26(2): 417-426. . (2015a) Legal Latins: Creating webs and practices of immigration status among Latin American migrants in London. Journal of Ethnic and Migration Studies 41(3): 493-511. . (2015b) International migration. In C. Cooper and J. Michie (eds) Understanding All Our Futures: Why Social Sciences Matter. Basingstoke: Palgrave Macmillan, pp. 176-191. 
and Bermudez, A. (2011) The gendering of political and civic participation among Colombian migrants in London. Environment and Planning A 43: 1499-1513.

—. (2015) Ambivalent citizenship and extra-territorial voting among Colombians in London and Madrid. Global Networks 15(4): 385-402.

McIlwaine, C. and Bunge, D. (2016) Towards Visibility: The Latin American Community in London. London: Trust for London. and Ryburn, M. (2018) Metropolitan mobilities: Transnational urban labour markets. In R. van Kempen and T. Schwanen (eds) Handbook of Urban Geography. Cheltenham: Edward Elgar.

Melde, S., Anich, R., Crush, J. and Oucho, J. (2014) Introduction: The South-South migration and development nexus. In R. Anich, J. Crush, S. Melde and J. Oucho (eds) A New Perspective on Human Mobility in the South. New York: Springer, pp. 1-20.

Mignolo, W. D. (2005) The Idea of Latin America. Malden, MA: Wiley-Blackwell.

OIM/IPPDH. (2017) Diagnóstico regional sobre migración haitiana. Buenos Aires: OIM/IPPDH.

Organisación Internacional para las Migraciones (OIM). (2015) Dinámicas Migratorias en América Latina y el Caribe (ALC), y entre ALC y la Unión Europea. Brussels: OIM. Orozco, M. (2017) Remittances to Latin America and the Caribbean in 2016. Washington, DC: Inter-American Dialogue. www.thedialogue.org/wpcontent/uploads/2017/02/Remittances-2016-FINAL-DRAFT.pdf (Accessed 7 December 2017).

Padilla, B. and Peixoto, J. (2007) Latin American Immigration to Southern Europe. Washington, DC: Migration Information Source.

Pellegrino, A. (2000) Trends in international migration in Latin America and the Caribbean. International Social Science Journal 52(165): 1468-2451. 
Portes, A. and Rumbaut, R. G. (2006) Immigrant America: A Portrait. Berkeley, CA: University of California Press.

Portes, A., Escobar, C. and Arana, R. (2008) Bridging the gap: Transnational and ethnic organizations in the political incorporation of immigrants in the United States. Ethnic and Racial Studies 30: 1056-1090.

Rodríguez, J. and Busso, G. (2009) Migración interna y desarrollo en América Latina entre 1980 y 2005. Santiago, Chile: CEPAL.

Rojas Pedemonte, N. and Silva Dittborn, C. (2016) La migración en Chile: breve reporte y caracterización. Santiago, Chile: Obersvatorio Iberoamericano sobre Movilidad Humana, Migraciones y Desarrollo. www.extranjeria.gob.cl/media/2016/08/informe_julio_agosto_2016.pdf (Accessed 7 December 2017).

Ryburn, M. (2016) Living the Chilean dream? Bolivian migrants' incorporation in the space of economic citizenship. Geoforum 76: 48-58.

—. (2018) Uncertain Citizenship: Everyday Practices of Bolivian Migrants in Chile. Berkley: University of California Press.

Sheringham, O. (2013) Transnational Religious Spaces: Faith and the Brazilian Migration Experience. Basingstoke: Palgrave Macmillan.

Sznajder, M. and Roniger, L. (2007) Exile communities and their differential institutional dynamics: A comparative analysis of the Chilean and Uruguayan political diasporas. Revista de Ciencia Política 27(1): 43-66.

Tijoux, M. E. (2016) Racismo en Chile: La piel como marca de la inmigración. Santiago, Chile: Ediciones Universitaria.

Tsuda, T. (1999) The motivation to migrate: The ethnic and sociocultural constitution of the Japanese-Brazilian return-migration system. Economic Development and Cultural Change 48(1): 1-31. 
UN DESA. (2014) World Urbanization Prospects: The 2014 Revision. New York: United Nations.

Vogt, W. (2013) Crossing Mexico: Structural violence and the commodification of undocumented Central American migrants. American Ethnologist 40(4): 764-780.

Wade, P. (2010) Race and Ethnicity in Latin America. London: Pluto Press.

_. (2017) Liberalism and its contradictions: Democracy and hierarchy in mestizaje and genomics in Latin America. Latin American Research Review 52(4): 623-638.

Wills, J., Datta, K., Evans, Y., Herbert, J., May, J. and McIlwaine, C. (2010) Global Cities at Work: New Migrant Divisions of Labour. London: Pluto. 